\title{
Beginning teachers' perceptions of mentors and access to communities of practice
}

Sam Shields and Megan Murray

Corresponding author: Samantha.Shields@ncl.ac.uk

School of Education, Communication and Language Sciences

Newcastle University

Newcastle

NG1 7RU

Tel: 01912086565

M.Murray@hull.ac.uk

School of Education

University of Hull

Hull

HU6 7RX

Tel: 01482466973

Disclosure Statement: The authors have no financial implications or benefits arising from direct application of this research.

Word Count: 8966 


\begin{abstract}
Purpose - The purpose of this paper is to explore beginning teachers' perceptions of the role of the mentor in the early stages of developing a professional identity. The beginning teachers in our study are defined as having been awarded qualified teacher status at the end of an initial teacher education programme or having completed their first term as a new teacher with responsibility for a class of pupils.

Design/methodology/approach - The research design was a qualitative, inductive study. The concepts of communities of practice, legitimate peripheral participation and power dynamics within a community underpinned this study. The data set was collected over a period of 18 months, through six focus groups and 40 questionnaires with beginning teachers across 34 schools altogether. The data set was analysed using interpretative phenomenological analysis (IPA).
\end{abstract}

Findings - The findings indicated that the ways in which mentors use their power to recognise (or not) the legitimacy of beginning teachers as being part of the school community influences the development of beginning teachers' professional identities. The thematic analysis of the data indicated the different types of support that mentors may provide: 'belonging', 'emotional', 'pedagogical' and 'space'.

Research limitations/implications - Further research into how mentors perceive their role in supporting new entrants into the profession is needed.

Originality/value - These findings are pertinent in England, as the increase in school-based initial teacher training provision will intensify the role of school mentors. These findings will be of value to other countries who are moving towards an increase in school-based teacher training.

Keywords - beginning teachers, mentors, support, communities of practice, power, mentoring standards

Paper type - Research paper

\title{
Mentor-mentee context
}

There has been a progressive move towards school based teacher education in England since the early 1990s, such as the introduction of School Centred Initial Teacher Training (Department for Education, 1992; 1993), the Graduate Teacher Programme (Department for Education and Employment, 1996) and expansion of Teach First (Department for Education, 2010). Since the UK government's white papers (Department for Education, 2010, 2016) on education, there has been a notable increase in the amount of school-centred initial teacher 
training provision. The authors of this paper prefer the term 'teacher education' as for them it is synonymous with growth and development of teachers; 'training' on the other hand suggests that teaching is a set of skills to be mastered. The authors however, use these terms interchangeably to ensure accurate citation of the work of others. The role of a school mentor is intensified in a model of teacher education where learning to teach largely takes place solely or predominantly in schools. Therefore, this paper focusing on beginning teachers' perceptions of the role of school mentors is significant. In the UK (in line with much teacher education provision internationally), the beginning teacher is supported by a school mentor (who is a more experienced teacher) during school placements. Studies such as those of Maguire (2001) and Sewell et al. (2009) have identified power imbalances between mentor and mentee. Pillen et al. (2013) identified relationships with mentors as one source of tension as beginning teachers develop their professional identities. Our study builds upon the work of Maguire (2001) and Sewell et al. (2009), arguing that mentors have a direct impact on the development of the professional identity of beginning teachers. Maguire (2001) has argued that the reasons why schools offer placements to beginning teachers is important, as this can influence the mentor-mentee relationship. Maguire (2001) also calls for greater training of mentors to improve the quality of the mentoring process. Grima-Farrell (2015) notes that mentors can be instrumental in reducing the anxiety levels of beginning teachers. This is also addressed by Lofthouse and Thomas (2014), who point out that a positive experience of being mentored is not universal. The mentors referred to in our study are (and the research outlined above relates to) school-based mentors. Other research, such as that of McIntyre and Hobson (2016) and Cameron and Grant (2017) indicate that mentors who are external to a school can have a different effect on trainee teachers.

The Carter Review of Initial Teacher Training (Carter, 2015) emphasised the importance of mentors in supporting trainee teachers (citing the work of Hobson and Malderez, 2013). A recommendation of the Carter Review was that a set of national standards for mentors should be developed by the Teaching Schools Council. The 'National Standards for school-based initial teacher training (ITT) mentors' are cited as 'Mentoring Standards' (2016) in the remainder of this paper, reflecting the terminology used by teachers and initial teacher educators. These non-statutory Mentoring Standards have been created to promote consistency in the quality of mentoring for trainee teachers. The Mentoring Standards were written after the research project reported in this paper had been completed. However, the inductive nature of the project has meant that the Mentoring Standards have been relevant when discussing the findings. 


\section{Research Questions}

In this study, the following questions were explored:

1) What experiences do beginning teachers note as important to their developing professional identity at one institution?

2) In what ways can these experiences be explained by legitimate peripheral participation and the power mentors have to allow or inhibit participation?

\section{Professional Identity}

Professional identity has been studied in many areas of the social sciences, and whilst it is often said to be ill defined (Beauchamp and Thomas, 2009; Beijaard et al., 2004), there are some overarching themes. Trede et al. (2012) describe professional identity as a sense of competence within a community. In addition, it can be seen as a framework through which competing tensions, priorities and ideas can be managed (MacLure, 1993; Olsen, 2008). Flores and Day (2006, p. 220) explain identity as 'an ongoing process which entails making sense and (re)interpretation of one’s own values and experiences’. For this study, then, professional identity is defined as 'a reflexive sense of competence, confidence and belonging in a community'. This definition draws together the overarching themes identified: the competence and confidence a teacher should have as a professional and her sense of belonging in a wider community, whilst maintaining a critical awareness of her practice. Understanding the concept of professional identity has been shown to be a powerful tool in helping beginning teachers make sense of themselves (Coldron and Smith, 1999; MacLure, 1993). Furthermore, understanding identity, especially issues that help or hinder the development of identity, can be useful for improving initial teacher education (Beauchamp and Thomas, 2009), especially when preparing beginning teachers for placement. For instance, an awareness of issues that may arise on placement and providing suggestions of coping strategies may develop the confidence of beginning teachers.

The concept of identity provides a framework for discussing our perceptions of self and also how others perceive us in different contexts and communities. For Wenger (1998, p. 145) 'building an identity consists of negotiating the meanings of our membership in social communities'. Similarly, Coldron and Smith (1999, p. 172) claim 'being a teacher is a matter of being seen as a teacher by himself or herself and by others; it is a matter of acquiring and then redefining an identity that is socially legitimated'. Developing a professional identity as a teacher depends on seeing oneself as competent, but also as a legitimate member of the 
community. Thus, there is a certain amount of self-agency required in the development of a professional identity, and a determined, enthusiastic beginning teacher who is allowed opportunities to contribute to the community should begin to develop an identity as a teacher. On the other hand, if not provided with opportunities to participate fully in the community, neither one's own opinion nor the opinions of others will support a developing professional identity. Therefore, an avenue through which we explore the beginning teacher's professional identity is that of legitimate peripheral participation and the power that allows, or does not allow, for legitimate peripheral participation and access to a community to take place.

\section{Learning, Communities of Practice, Legitimate Peripheral Participation and Power}

The lens of a community of practice has been used to examine teacher learning in school communities (for example, Woodgate-Jones, 2012; Trust and Horrocks, 2016; Wright et al. 2017). Although, Vangrieken et al. (2017) highlight that 'community' can be a fuzzy concept, they argue it does have a key role to play in understanding teachers' professional development. A study of student teachers in England (Woodgate-Jones, 2012) started from the stance that schools have three characteristics that resonate with the concept of communities of practice. First, there is a shared domain of interest - pupil learning. Second, there are shared activities, such as meetings and informal conversations to facilitate pupil learning - the community. Third, teachers are practitioners (albeit with differing levels of experience) who develop a shared repertoire of practice. Learning requires movement from the fringes of the community of practice to full participation by mastering skills, knowledge and sociocultural practices. Through participation, a new member of a community will face a range of experiences, including developing relationships with other members of the community and encountering processes and traditional ways of behaving within the community. Such experiences may define, promote or limit further learning, and affect the beginning teacher's sense of belonging to the community and her growing professional identity as a teacher.

Lave and Wenger summarise the complexities of the newcomer entering a community with the term 'legitimate peripheral participation', and use this term as a means to discuss the 'process by which newcomers become part of a community of practice' (Lave and Wenger, 1991, p. 29). Lave and Wenger (1991, p. 42) see peripherality as an opening into the workings of the community, but also recognise that 'unequal relations of power' are inherent in communities of practice, and that 'hegemony over resources for learning and alienation from full participation are inherent in the shaping of the legitimacy and peripherality of 
participation'. In further reflection about legitimate peripheral participation, Wenger (1998)

admits that full participation is not always achieved; in fact, some participants remain marginal to a community. Johnston’s (2016) study of problematic student teacher school placements in Scotland is a good example of peripheral participation.

Equally, some communities will welcome novices, induct them into the communal practices, and provide support that encourages active membership in the community. Trust and Horrocks' (2016) study of teachers developing through professional learning communities is a good example of this. In return, novices bring fresh ideas that allow the community to grow. However, as noted by Handley et al. (2006), threats to the status quo may cause powerful practitioners to deny or inhibit access to the community. Power, therefore, has a key role in determining levels of legitimate peripheral participation, which in turn may have an impact on beginning teachers' professional identity. Emad and Roth’s (2016) insightful work about quasi-communities is pertinent and can be applied to teachers. The relationship beginning teachers have with their mentors when they are newly qualified teachers (NQTs) can be characterised by a greater sense of equality than when they are 'training' (Hobson et al., 2009). This is different from the more typical expert-novice relationship associated with the community of practice when beginning teachers are completing their formal teaching practices.

\section{Study context}

The research was conducted when both authors were lecturers at the same coastal satellite campus of a university in the north of England. The researchers were personal tutors to student teachers undertaking undergraduate and postgraduate routes into teaching. In the capacity of being personal tutors, the researchers experienced the role of supporting tutees who had lost their confidence as a result of their interactions with school mentors. Equally, the researchers met with tutees who were full of enthusiasm for teaching largely because they had such a positive relationship with their school mentor. The tutees trained through a threeyear undergraduate programme called BA Primary Teaching which qualified them to teach pupils between the ages of 5 years and 11 years. The one-year post graduate certificate enabled trainees to teach pupils between the ages of 3 years and 7 years (nursery and infant children). The tutees are referred to as beginning teachers for two reasons. First, pragmatically this phrase encapsulates the stage at which the participants took part in the study. The data set was captured from participants at the beginning of their teaching career; they had just finished their training and received qualified teacher status (QTS), or they had 
recently completed their first term teaching as an NQT. Second, the phrase 'beginning teacher' embodies the researchers own philosophical stance regarding participants. The participants are viewed as part of the 'teacher community', and terminology that is representative of this is used. The research focuses on beginning teachers' perceptions of the school community in which they learn to teach, and how the community and mentor support provided can exacerbate or diminish the tensions surrounding the development of beginning teachers’ professional identities. The beginning teachers' experiences during their school placements can be shaped by the way their mentors are assigned in initial teacher education.

Partnership schools (schools which offer placements for university-based beginning teachers) are contacted by the university. The school then states how many places it is able to offer. The school then makes its own arrangements with its teachers as to who will act as a mentor. The university offers mentor training to teachers and will pay the supply teacher costs of the school to enable its teachers to undertake the mentor training. Mentor training is taken up by $55 \%$ to $65 \%$ of schools, with at least one mentor per school attending in any given year. Schools which are new to a partnership with the University endeavour to have their mentors attend the mentor training. The university pays the school for the placements it offers. It is at a school's discretion as to how these payments are used. The mentorship may be a one-to-one pairing (typically a class teacher and a beginning teacher) or it may be that one mentor (often a more senior member of staff) has overall responsibility for a number of mentees, and the class teacher acts as an informal mentor on a day-to-day basis. University-based tutors act as a liaison between the university, the school and the student.

\section{Data Collection}

This project adopted an interpretive and inductive approach. Data for this study was collected through focus groups and questionnaires across both routes. The credibility of the data was supported through triangulation through the use of two research methods. Six exploratory focus groups were carried out with 20 beginning teachers (two focus groups contained four participants, and four focus groups consisted of three participants) who were 18 weeks into their NQT year. Each focus group was semi-structured in approach and lasted between 30 minutes and one hour. Questions were written by the lead researcher and reviewed by three colleagues, and then revised for clarity and improved research focus and purpose. The intention of the focus group was to ask participants about their experiences of being mentored when they were training to become teachers. However, there is often a tendency to compare 
'past and present' (Hargreaves and Woods, 1984) and at times the newly qualified teachers did compare their experiences of mentoring as trainees with their experiences as NQTs. The focus group interviews were transcribed verbatim by a professional transcription service. The findings of the focus groups were used to inform the questionnaire design.

Like the focus group schedule, the questionnaire was revised for clarity and focus. The questionnaire was developed in response to the findings of the focus groups. The questionnaire consisted of 27 questions, of which 17 were closed and 10 were open. The focus groups were conducted with participants who had graduated from both courses at an NQT conference hosted by the institution. We received 40 completed questionnaires. The questionnaire was given to two sets of participants (from a BA Primary Teaching programme and a PGCE 3-7 years programme) who had just completed their final teaching placement and who were to be awarded QTS. The rationale for the sample was to see if 'psychological distance' (Kross and Ayduk, 2011) made perceptions of mentors less emotionally charged.

The respective return rate for the questionnaires was 26 per cent (25 out of 96 for BA Primary) and 19 per cent (15 out of 78 for PCGE 3-7). Overall, the response rate was 23 per cent; this is in line with the response rates of other questionnaires about teacher identity. For example, in the Chong and Low (2009) study, at the end of the first year of teaching their response rate was 19 per cent (116 out of 605). The Struyven et al. (2012) study of trainee primary teachers had a higher questionnaire response rate of 58 per cent (1805 of a first year trainee teacher cohort), but this may reflect the easier access to participants who were still attending university. Our questionnaire was given to participants via an online email link or as a paper copy. The email link was sent to participants whom the researchers were unlikely to see face-to-face, and the paper copy was given to beginning teachers with whom we still had direct contact. Questionnaires were collected in such a way that participants' anonymity could be maintained. Whilst some participants answered questions in a manner that revealed their identity, the data has been handled in a manner that preserves confidentiality.

\section{Data Analysis}

The focus group transcripts and open-ended questionnaire responses were analysed with an interpretative phenomenological approach (IPA). Smith and Osborn (2015) acknowledge that IPA is generally carried out using small sample sizes and that the sample is fairly homogeneous (in this instance beginning teachers). The emphasis in IPA is to understand the perceptions of the participants. The use of IPA supported our intention to include as much of 
the original data as was feasible to provide 'thick description' (Geertz, 1973) of the events beginning teachers described as important early in their first teaching position or on placement. It is anticipated that this should enable others to compare the data to their own experiences or studies in this field to support the transferability (Lincoln and Guba, 1985) of the findings to other contexts. Smith and Osborn (2008) provide a thorough description of the process through which the data is handled in IPA, but encourage the researcher to adapt the method of IPA to her own way of working and specific research topic. Wilkinson (2015, p. 202) argues that focus group research lends itself to a 'wide variety of different types of data analysis ... [including] phenomenological'. Wilkinson (2015) suggests that in certain circumstances, it is possible that focus groups will facilitate more personal disclosure than individual interviews.

Annotated transcripts were reread, with memos made in the margin documenting emerging themes. Themes were listed and then clustered according to similarities; some themes emerged as overarching concepts. This iterative process of interpreting primary sources, and then assuring the interpretation was true to the primary sources, continued throughout the entire analytical process. Once researchers had identified themes within the first case, they were organised into a table along with locations of supporting text within the transcript. Researchers then met to discuss their individual interpretations and came to an agreement about identified themes. This can be likened to the principle of the audit trail discussed by Lincoln and Guba (1985), as the researchers initially worked independently of each other to identify themes. Whilst IPA typically involves an in-depth analysis of a set of case studies, the results of the analysis do not stand on their own, but rather are subsequently discussed in relation to the extant literature. Thus, the project also adopted the process of 'sensitisation' (Blumer, 1954), meaning that the data was read with consideration of themes identified in research literature in this area (Hobson et al., 2009; Orland-Barak and Hasin, 2010; Roehrig et al., 2008). New literature was read based on the emerging themes, and researchers compared these findings to their own, either to confirm findings or to raise questions. Subsequent data was analysed in light of the literature, until a final set of themes was established. Several steps were taken to enhance the trustworthiness of the data. A 'debriefing by peers' (Lincoln and Guba, 1985, p. 109) of an earlier version of this article was undertaken by academic colleagues not involved in the research project for 'challenge' and 'legitimation'. A final draft of the article was sent to seven participants who had provided a personal email address (as participants no longer had access to their university email accounts) asking for comments. We received one response: 
I found your article very accurate in regards to the experiences felt by 'beginning teachers'. It was an interesting read and personally made me reflect upon my own practice as a mentor ... The trainees bring with them confidence and a drive to succeed ... Every aspect of mentoring is important but as your article suggests the 'acceptance' of a trainee into a school is paramount to their success. (*Participant, email correspondence, 9 November 2016).

The researchers are grateful for this response and take confidence in these comments, but the researchers are not suggesting that this is in any way a sufficient response to claim 'member checking' (Lincoln \& Guba, 1985) of the research findings. Inevitably, this means the findings presented here reflect one amongst other possible interpretations of the data.

\section{Findings and discussion}

The analysis of the data revealed many incidences where beginning teachers recognise factors that influence their sense of belonging, competence and overall identity. Some of these instances contribute to a positive, strong professional identity; at other times, events cause beginning teachers to doubt themselves. In most of these cases, there is an element of power exhibited by the mentor that supports or inhibits the development of a strong professional identity. These events were categorised by looking at the type of support they offer, or deny, the beginning teacher. Four types of support that are important to beginning teachers emerged from the data, and these were subsequently developed into four themes:

- 'Belonging' support (this featured events that demonstrated to beginning teachers that they were wanted in the classroom and school and made them feel welcome);

- Emotional support (this featured giving encouragement and boosting confidence levels);

- Pedagogical support (this featured passing on advice and guidance to support beginning teachers' development in their classroom practice);

- 'Space' support (this featured giving beginning teachers the freedom and autonomy to try out their own ideas).

\section{'Belonging' support}


For beginning teachers to feel that they were wanted and welcomed in the classroom by their mentor and school was important. This was facilitated by a sense of teamwork and collaboration. 'Apprentices' are often described as being on the boundary of a community of practice. Like others (e.g. Bathmaker and Avis, 2005), we see Lave and Wenger's (1991) work as relevant in the shift in identity as beginning teachers develop their expertise of students as they become teachers. Maynard (2000) identified the emphasis placed by PGCE students on being part of the school in which they undertook their placements. Our findings also indicated that what beginning teachers appeared to value the most was feeling accepted centrally into the life of the classroom and wider school environment. In many cases, it is within the mentor's power to ensure trainees are welcomed into the school, and mentors are often very inclusive and inviting with beginning teachers. The quotes below give examples of beginning teachers feeling that they 'belonged' in the school community.

And I've always been lucky to be part of a team where the [beginning] teachers are included. I went to the staff meetings and training days, I always felt as an equal very much anyway, and I took my turn at being the person at the front of the class as well, you know? (Claire, focus group 1, respondent 3)

I was welcomed at the school from the start. I was treated like a teacher from the moment I walked in - by all staff at the school. As time went on, I felt as though I earned the respect of my colleagues ... We work together every day to give the best for the children but still find time to share humour and personal relationships that serve to make us a better team. (Questionnaire respondent 16, male, aged 35-44)

My placement has been great. My teacher is my mentor. She has introduced me to everyone, shown me where everything is, and even told me who to ask if I need something. At first she planned with me every evening, and helped me with some good ideas for teaching. Now I am planning, but she looks over my plans, tells me when they look good, but critiques them as well when she sees ways they might be better. I am learning a lot from her. (Questionnaire 7, female, aged 18-24)

The non-statutory Mentoring Standards (2016) that have been developed to 'help provide greater coherence and consistency to the school-based mentoring arrangements for trainee teachers' (p. 3) are relevant to these findings. The standards do not talk explicitly about 'belonging', but this is arguably implied in Standard 1, 'The mentor should ... be 
approachable' (p. 11) and in Standard 3, 'The mentor should ... encourage the trainee to participate in the life of the school' (p. 12). The Mentoring Standards arguably imply that mentors should demonstrate behaviours which will be commensurate with beginning teachers being made to feel welcome within the school community.

\section{Not belonging}

This sense of belonging was not ubiquitous in the research findings, and not all mentors used their role to ensure beginning teachers felt recognised as part of the community. At times, mentors used their powers to prevent participation within the school. Levine and Moreland (1991) indicated that some teachers may not want to take on the role of mentor, leading to feelings of resentment causing mentors to deliberately withhold knowledge. Thus, a lack of power in choosing to be a mentor may result in trying to regain some level of personal control. Beginning teachers in this study describe experiences of being ignored and a belief that mentors are 'lumbered' with them. The following quotes describe situations with individuals or groups in the school community that had a negative effect on the development of the professional identities of beginning teachers.

Not all the settings were very open to having a student teacher at them. ... My third one was awful. They just didn't want anybody there at all ... They didn't help you.... The fact I wasn't included in conversations in the staffroom. I got to the classroom one day, prepared everything, got ready, and it was oh, we're not doing that today. I was like you could have told me that yesterday! (Melanie, focus group 1, respondent 2)

Yes, I think it's important for the students that they feel welcomed at school and schools actually want them there, because it's really hard when you're that student there and you're there seven weeks and nobody helps you or talks to you or wants you there ... because it's very hard to get through a placement like that. (Lucy, focus group 1 , respondent 4)

These quotes indicate feelings of not being wanted. This captures the perceptions of beginning teachers as being on the periphery of school life and as little more than a hindrance to the school community. In situations such as these, mentors have either not used their power to help the beginning teacher gain acceptance, or they have used their power to 
alienate the trainee. Beginning teachers were also aware of the 'workload' involved in mentors having to look after students.

I think we were a hassle, more work for them, because they had to observe us and write us up, and I think they just found that we were just another thing on their list of things to do, adding to their workload, I don't know. (Melanie, focus group 1, respondent 2)

And I think sometimes the conversations are between the University and the headteacher and not the person who's going to be lumbered with you. So they think, she's agreed to have them, but they haven't been asked. (Claire, focus group 1, respondent 3)

Drawing on the work of Maynard (1996), Hobson (2002) acknowledges that the mentoring of student teachers is constrained by school-based mentors' 'inevitable "juggling of priorities" in the face of the "overwhelming demands" of school life ... and the administrative demands of [ITE]' (p. 16). Clearly, mentors have the power to prioritise their workload; in situations where beginning teachers are assigned to them, some mentors may well not find the beginning teachers a high priority.

The Mentoring Standards (2016) start to challenge the culture of the additional workload burden attached to mentoring and conceptualise mentoring as a high status role which recognises expertise. The case studies used as examples of 'best practice' for mentoring in the Mentoring Standards show that time is a prerequisite for good quality mentoring, such as the pairing up of mentors to undertake joint observations. The emphasis placed on mentoring by some schools is therefore reflected in the workload allocation of their mentors. This ethos will certainly enable an organisational structure which facilitates effective mentoring practices. However, the Mentoring Standards are not statutory, and the 'optional' nature of undertaking mentoring is in contrast to other professions, such as medicine. The British Medical Association (BMA, 2017) characterises mentoring as tending to involve 'an experienced individual using their greater knowledge and understanding of the work or workplace to support the development of an inexperienced colleague'. Mentoring is built into the General Medical Council's policy documents (for example, Good Medical Practice, 2013, paragraph 10 and 42). Therefore, a culture of mentoring threads through the medical 
profession with the newest qualified doctors being recognised as being able to offer some expertise to others. The role of schools in facilitating longer-term succession planning of experienced mentors is emphasised in the Mentoring Standards. The Mentoring Standards case studies demonstrate schools can give mentors enough time to mentor effectively. Mentors 'should be given sufficient time as part of their timetable to observe trainees, provide constructive feedback and to have meetings and discussions outside of the classroom to monitor progress' (2016, p. 7). The expertise of mentors is rightly emphasised within the Mentoring Standards, but this may accentuate the power imbalance between the mentor as 'teacher-expert' and the mentee as 'teacher-learner'.

The very nature of being a learner appeared to exacerbate the sense of 'not belonging' for some beginning teachers. The nature of being a beginning teacher seemed to emphasise their peripheral status due to not being able to take on the complete teacher role and an understanding of the placement not being the same as being a 'real' teacher. The second of the following two quotes may indicate that a lack of strong mentoring support can expose students to being undermined by others within the school context.

I feel that there have been some difficult situations with teaching assistants where they have undermined my ideas. I feel that reduced my confidence in bringing forth new ideas/pedagogy. (Questionnaire respondent 7, female, aged 25-34)

In my last observation, it was picked up that he's [Teaching Assistant] talking over the top of me, so the kids don't know whether to listen to him or don't know whether to listen to me and that's reflecting back on me. (Bryony, focus group 6, respondent 1)

Lofthouse and Leat (2013) have emphasised the importance of dialogic relationships between mentors and mentees and cite evidence of mentors 'telling' students how to teach. The Mentoring Standards do not appear to explicitly mention that possibility of beginning teachers feeling undermined. However, Standard 1 does state that mentors should 'use appropriate challenge to encourage the trainee to reflect on their practice' (p. 11), and this ties in more generally with mentors having suitable personal qualities to work with mentees. The Mentoring Standards are explicit in stating that a mentor should be a teacher with exemplary practice in teaching and learning; however, concerns about personality clashes or the reluctance of teachers to become mentors is not addressed. Research (such as Sudzina et al., 
1997; Hobson, 2002) have argued that 'personality clashes' can cause difficulties in the mentor-mentee relationship. Currently, the Mentoring Standards do not offer any advice as to how to avoid such a conflict. However, vignettes from Sudzina et al. (1997) indicate that unrealistic expectations of student teaching, disagreements over teaching styles and mentees not engaging in reflection can all be sources of tension. These sources of tension can make it difficult for a mentor to respond to a mentee with empathy.

\section{Emotional Support}

The emotional support given by mentors was an important feature in ensuring that beginning teachers had a successful classroom experience. The emotional support offered indicated a step beyond the typical 'master-apprentice' relationship which may typically characterise the student-mentor relationship. It also indicated a clear sense of belonging to beginning teachers, as their relationship with their mentor appeared to be underpinned by an attitude of 'being in it together'. Arguably, mentors have the power to choose how much of their time and support they will give beginning teachers as well as the power to withhold such support. Those who choose to provide high levels of support have a marked positive effect on beginning teachers' identities, exemplified by the following:

I was very fortunate to have such a supportive and experienced mentor - he has shared so much with me this year. You can't read that in any book. (Questionnaire 16, male, aged 35-44)

Working closely with my mentor each week has been very beneficial in terms of my confidence, and my development. We have highlighted in my TDP [Teaching Development Profile] where I am meeting the Teaching Standards, and also discussed personal targets. My mentor is very supportive, and I feel I can draw upon their expertise and knowledge in order to achieve the very best, and gain experience of good practice (Questionnaire respondent 14, female, aged 18-24).

Beginning teachers who work with mentors who withhold emotional support are less confident and often turn to alternative networks for comfort.

I have worked with a class teacher who has been reluctant to offer any praise at all during teaching practice which has often led to a lack of confidence and negative selfperception of my teaching. (Questionnaire respondent 7, female, aged 25-34) 
I think it's support for like placements as well, like one of my placements was really bad and like other people had really bad placements but I think just that support and like you could go to another friend and just ask for their help or what would I do about, and just get like, a bit of your confidence back. (Michelle, focus group 6, respondent 2)

The Mentoring Standards (2016) state that mentors should 'offer support with integrity, honesty and respect ... use a range of effective interpersonal skills to respond to the needs of the trainee'. This indicates that a level of empathy is expected from mentors. However, as teaching is already a job which requires a high degree of 'emotional labour' (Hochschild, 2012) when working with pupils and their parents, it is perhaps not realistic for mentors to offer as much emotional support to mentees as they may wish for. The Mentoring Standards, perhaps implicitly recognising the tension between the emotional support required by beginning teachers and the emotional reserves that mentors are able to draw upon, states that the standards should be used in part 'to understand what support they can expect from their school-based mentor' (2016, p. 10). Our data indicated the emphasis that beginning teachers place on emotional support which seemed on par with their need for pedagogical support.

\section{Pedagogical Support}

The pedagogical support beginning teachers were offered featured advice and guidance related to classroom practices, planning and assessment. The pedagogical support also featured constructive criticism with targets for development. Mentors who offered pedagogical support were generally approachable and helped to answer queries.

My school mentor has been vital in my development. She is also my class teacher so sees my teaching every day and supports me by making suggestions etc. as well as formal observations. I feel comfortable to ask her about any aspect of my training and practice that I am unsure of. Without this support I do not think I would have developed my confidence so well in these areas. (Questionnaire respondent 17, female, aged 25-34)

Pedagogical support appeared to be most helpful to students when it was regular and students felt that they had a close working relationship with their mentor. Questionnaire analysis of the PGCE route showed 38 per cent of beginning teachers saw their mentor more than once a 
week, 46 per cent once a week and 15 per cent once every two weeks. This indicates that for many participants, they had regular feedback from their mentor. Beginning teachers also felt that their mentor was a role model and could offer good examples of practice.

My mentor in my most recent placement has been extremely supportive (as mentioned previously). They are extremely welcoming, and I feel that they acknowledge the positive elements of my teaching whilst always striving for improvement. My mentor has given me excellent pedagogical advice, and has also made me feel like a valued member of the staff. (Questionnaire respondent 14, female, aged 18-24)

In all these examples, the mentors seem to use their power as the expert to guide the beginning teacher. These mentors appear to recognise the need to act as a role model, as an adviser, and as a source of information that the beginning teacher can draw upon to improve her practice. In these situations, power can be construed as a source of supporting forward progress as well as maintaining a sense of equilibrium and inculcating the beginning teacher into being part of the school community.

\section{'Space' Support}

Beck and Kosnick (2000) have argued that many mentors may not give beginning teachers ample opportunities to 'innovate'. Lave and Wenger (1991, p. 123) draw attention to the 'conflict between continuity and displacement'. On the one hand, novices need to engage and fit into existing practices, but at the same time they may have new ideas and have an interest in making changes to the community. Mentors have the power to provide support for beginning teachers to be creative and innovate with their practice.

My mentor/class teacher on Spring placement. She was influential because she allowed me the freedom, support and guidance to find my own identity within her classroom. She encouraged me to be creative and to take ownership of the planning and assessment, as well as supporting me to lead meetings by the end of the placement. She was extremely knowledgeable and taught me the value of self-study to improve practice. (Questionnaire respondent 8, female, aged 25-34)

I've been really lucky because... I've been left to just do whatever I want to do and what I feel is best and it just, the head just trusts all of the staff to do that. So even as 
an NQT I'm given that freedom really to do what I think is best. (Focus group 2, respondent 1 , Vanessa)

However, not all beginning teachers experienced the space and freedom to try out new ideas.

My mentor was the person who kind of wanted her classroom back! [laughs] And I've changed it to being more free-flow and the TAs [Teaching Assistants] were doubting that I was doing it right, because it was quite an isolated little school, and why aren't you giving them things to stick on here, there and do that? So that I had to come across ... when you're surrounded by people who are doubting what you're doing, then you start thinking 'Oh gosh!' And you want to go to another school just to get some confirmation that you are doing it right. (Lucy, focus group 1, respondent 4)

Furthermore, as suggested by the final quote in this section, mentors can also challenge or prevent beginning teachers from trying something on their own.

The most challenging thing about being a trainee is the fact that despite being so eager to take over the teaching and developing our own teaching style, we are still guests in that school and classroom. Obviously every school is different, and for different reasons, but sometimes having to defer to someone else's judgement when you feel that you would like to try something a different way can be very challenging. (Questionnaire respondent 8, female, aged 25-34)

This last quote indicates the frustration that can be felt by beginning teachers when they feel constrained and do not perceive that they are being given enough 'space' to try out different ideas. A mentor may choose not to provide space, because they lack confidence in the beginning teacher, or because they feel pressure regarding the learning that is occurring in their classroom. But they may also be reluctant to engage with new ideas or approaches, as these present a challenge to the status quo and the way in which the community operates. Barnett (2011, p. 33) discusses the different dimensions of learning spaces. Applying the concept of a learning space to a beginning teacher's lesson might be a consideration of the extent to which they have ownership of the activity, the extent to which they are accountable for pupil learning and the tacit rules that frame the lesson. Barnett dissuades the reader from using the different dimensions of learning spaces as a crude matrix, but it is a useful baseline to understand the extent to which beginning teachers have enough space to learn to be a teacher. 
Power may be exerted by the mentor in a way that intentionally relegates the beginning teacher to the periphery of the school community through a lack of space to learn. The accountability issues that teachers face in relation to the progress of pupils in their care means that beginning teachers can be sidelined if the children do not appear to be advancing sufficiently. The issue of pupil progress can stop teachers from developing expertise as a mentor, because their class will not necessarily have a student teacher every year. Of course, a mentor is not necessarily the class teacher, but often acts in this role even if this is only acknowledged informally. It seems that the Mentoring Standards are a move in the right direction to support mentees and mentors and certainly reflect the issue of 'belonging' and 'pedagogical' support that were raised by beginning teachers in this study. The wider macro issues facing the school community of time pressures due to heavy workloads and accountability are not easily solved. However, if the Mentoring Standards were to become statutory there would be additional impetus to tackle these issues to support mentors and mentees.

\section{Limitations of the study}

This study has a number of limitations. First, it is a small-scale study carried out at one university-school ITE partnership programme (across 34 schools) in England, so the researchers cannot claim generalisability. Second, the beginning teachers that participated in our study were training to be early years and primary school teachers. Those undertaking training to become a secondary school teacher may have different perceptions of mentors. Third, we were unable to triangulate our findings through observing the relationships between mentors and mentees which would have added to the richness of the data we collected. Fourth, although we had data on the types of schools beginning teachers undertook their placements in, the data set was too small to draw any meaningful conclusions from this. Fifth, the locations of many of the placements were in small, coastal schools. The mentors at these schools may have different demographic characteristics to the teaching population as a whole in England (Muijs, 2017). Therefore, again, the study does not claim to be representative of all teacher-mentors.

\section{Conclusion}

This paper has raised some interesting tensions and complexities within the mentoring process for beginning teachers, alluding to the power the mentor wields to support or 
undermine the beginning teacher's placement experience. We believe this article may be a useful text to facilitate discussions with teachers we are training as mentors. The positive accolades given by beginning teachers of excellent mentors should be celebrated. Equally the constraints and challenges mentors face should be debated in relation to the school contexts in which they work. It is within the mentor's control to ensure that the beginning teacher feels welcomed and supported and receives appropriate emotional and pedagogical support, as well as the space to trial their own ideas. Ensuring that beginning teachers feel welcomed into a school community, and are encouraged and allowed to participate in all aspects of the community, appears to be significant in the development of their professional identity as teachers. This study indicates that beginning teachers perceived the most effective mentors as the ones who 'go beyond' pedagogical support and are also able to offer emotional support as well as allow them the freedom to try new ideas. This brings into question the complexity of the role of mentors and how these additional forms of support for beginning teachers can be facilitated consistently within and across school communities. The Mentoring Standards (2016) appear to reflect many of the needs of beginning teachers in terms of 'belonging' and 'pedagogical support', and it will be interesting to see to what extent they impact beginning teachers' experiences during school placements. We anticipate the next stage of this research will be to understand mentors' perceptions of the mentoring process. We hope to draw out the reasons that mentors undertake mentoring roles and the possible power dynamics that may underpin school communities to further explore how these factors may shape the development of beginning teachers' professional identities.

\section{Acknowledgements}

Thank you to the three reviewers who provided insightful feedback on an earlier version of this paper. We would also like to thank the Editor and Associate Editor who provided meticulous feedback to improve the clarity of the paper. 


\section{References}

Bathmaker, A. and Avis, J. (2005), "Becoming a lecturer in further education in England: the construction of professional identity and the role of communities of practice”, Journal of Education for Teaching, Vol. 31 No.1, pp. 47-62.

Barnett, R. (2011), “Chapter 2 Lifewide education: a transformative concept for higher education”, in Jackson, N.J. (Ed.), Learning for a complex world A lifewide concept of learning, education and personal development, AuthorHouse, Bloomington, pp. 22-38.

BMA (2017,) “Progressing your career - mentoring”, available at:

https://www.bma.org.uk/advice/career/progress-your-career/mentoring (accessed 1st April 2017).

Beck, C. and Kosnick, C. (2000), “Associate teachers in pre-service education: clarifying and enhancing their role”, Journal of Education for Teaching, Vol. 26 No. 3, pp 207-224.

Beauchamp, C. and Thomas, L. (2009), “Understanding teacher identity: An overview of issues in the literature and implications for teacher education”, Cambridge Journal of Education, Vol. 39 No. 2, pp. 175-189.

Beijaard, D., Meijer, P.C. and Verloop, N. (2004), "Reconsidering research on teachers' professional identity”, Teaching and teacher education, Vol. 20 No. 2, pp. 107-128.

Blumer, H. (1954), "What is Wrong with Social Theory”, American Sociological Review, Vol.18, pp. 3-10

Cameron, D., \& Grant, A. (2017). “The role of mentoring in early career physics teachers’ professional identity construction”. International Journal of Mentoring and Coaching in Education, Vol 6 No. 2, pp. 128-142.

Carter, A. (2015) The Carter Review of initial teacher training (ITT), Crown copyright, January 2015 
Chong, S. and Low, E-L. (2009), “Why I want to teach and how I feel about teachingformation of teacher identity from pre-service to the beginning teacher phase”, Educational Research for Policy and Practice, Vol. 8 No. 1, pp. 59-72.

Coldron, J. and Smith. R. (1999), “Active location in teachers' construction of their professional identities”, Journal of Curriculum Studies, Vol. 31 No. 6, pp. 711-726.

Department for Education (1992), The new requirements for initial teacher training (Circular 9/92), London: DfE.

Department for Education (1993), The Government’s Proposals for the Reform of Initial Teacher Training, London: DfE

Department for Education and Employment (1996), Graduate Teacher Programme: Consultation Paper, London: DfEE

Department for Education (2010), The Importance of Teaching, November 2010

Department for Education (2016) Educational Excellence Everywhere, March, 2016

Emad, G. R. and Wolff, M. R (2016), “Quasi-communities: rethinking learning in formal adult and vocational education”, Instructional Science, Vol. 44 No. 6, pp. 583-600.

Flores, M. A. and Day, C. (2006), “Contexts which shape and reshape new teachers’ identities: A multi-perspective study”, Teaching and teacher education, Vol. 22 No. 2, pp. 219-232.

Geertz, C. (1973), The interpretation of cultures: selected essays, Basic Books, New York

General Medical Council (2013) Good Medical Practice, GMC

Grima-Farrell, C. (2015), Mentoring pathways to enhancing the personal and professional development of pre-service teachers, International Journal of Mentoring and Coaching in Education, Vol. 4 No. 4, pp. 255-268 
Handley, K., Sturdy, A., Fincham, R. and Clark, T. (2006), “Within and beyond communities of practice: making sense of learning through participation, identity and practice”, Journal of management studies, Vol. 43 No.3, pp. 641-653.

Hargreaves, A. and Woods, P. (Eds) (1984), Classrooms and Staffrooms: The Sociology of Teachers and Teaching, Milton Keynes, Open University Press.

Hobson, A. J. (2002), “Student teachers' perceptions of school-based mentoring in initial teacher training (ITT)”, Mentoring and Tutoring, Vol. 10 No.1. pp. 5-20.

Hobson, A. J., Ashby, P., Malderez, A. and Tomlinson. P.D. (2009), “Mentoring beginning teachers: What we know and what we don't”, Teaching and Teacher Education, Vol. 25, No. 1, pp. 207-216.

Hobson, A.J. and Malderez, A. (2013) "Judgementoring and other threats to realizing the potential of school-based mentoring in teacher education", International Journal of Mentoring and Coaching in Education, Vol. 2 No. 2, pp.89-108.

Hochschild, A. (2012), The Managed Heart Commercialization of Human Feeling, University of California Press Ltd, London, $3^{\text {rd }}$ ed.

Johnston, D.H. (2016), “'Sitting alone in the staffroom contemplating my future’: communities of practice, legitimate peripheral participation and student teachers' experiences of problematic school placements as guests”, Cambridge Journal of Education, Vol. 46 No. 4, pp. 533-551.

Kross, E. and Ayduk, O. (2011), "Making Meaning out of Negative Experiences by SelfDistancing”, Directions in Psychological Science, Vol. 20 No. 3, pp. 187-191.

Lave, J. and Wenger, E. (1991) Situated learning: Legitimate peripheral participation. Cambridge University Press, Cambridge. 
Levine, J. M. and Moreland, R. L. (1991), “Culture and socialization in work groups”, in Resnick, L.B., Levine, J.M. and Teasdale, S.D. (Eds), Perspectives on socially shared cognition, American Psychological Association, Washington, D.C, pp. 257-279.

Lincoln, Y. S. and Guba, E. (1985), Naturalistic Inquiry, Sage publications, London.

Lofthouse, R. and Thomas, U. (2014), “Mentoring student teachers; a vulnerable workplace learning practice”, International Journal of Mentoring and Coaching in Education, Vol. 3 No.3, pp.201-218.

Lofthouse, R. and Leat, D. (2013), “An activity theory perspective on peer coaching”, International Journal of Mentoring and Coaching in Education, Vol. 2 No.1, pp.8 - 20.

McIntyre, J., \& Hobson, A. J. (2016), “Supporting beginner teacher identity development: External mentors and the third space”. Research Papers in Education, Vol. 31 No.1, pp. 133158.

MacLure, M. (1993), “Arguing for your self: Identity as an organising principle in teachers’ jobs and lives”, British Educational Research Journal , Vol. 19 No. 4, pp. 311-322.

Maguire, M. (2001), "Bullying and the postgraduate secondary school trainee teacher: An English case study”, Journal of Education for Teaching, Vol. 27 No.1, pp. 95-109.

Maynard, M. (1996) The limits of mentoring: the contribution of the HE tutor to primary student-teachers' school-based learning, in: J. Furlong \& R. Smith (Eds) The Role of Higher Education in Initial Teacher Training. London: Kogan Page.

Maynard, T. (2000), "Learning to teach or learning to manage mentors? Experiences of school-based teacher training”, Mentoring and Tutoring, Vol. 8 No. 1, pp.17-30.

Mujis, D. (2017), “Improving schools in coastal towns: evidence from secondary data analysis”, Education research seminar, 9 March, Newcastle, Newcastle University.

Olsen, B. (2008), “How reasons for entry into the profession illuminate teacher identity development”, Teacher Education Quarterly, Summer 2008, pp. 23-40. 
Orland-Barak, L. and Hasin, R. (2010), “Exemplary mentors’ perspectives towards mentoring across mentoring contexts: Lessons from collective case studies”, Teaching and Teacher Education, Vol. 26 No.3, pp 427-437.

Pillen, M., Beijaard, D. and den Brok, P. (2013) "Professional identity tensions of beginning teachers”, Teachers and Teaching, Vol. 19 No.6, pp. 660-678.

Roehrig, A. D., Bohn, C.M., Turner, J.E and Pressley, M. (2008), “Mentoring beginning primary teachers for exemplary teaching practices”, Teaching and Teacher Education, Vol. 24 No. 3, pp. 684-702.

Sewell, K., Cain, T., Woodgate-Jones, A. \& Srokosz, A. (2009), "Bullying and the postgraduate trainee teacher: a comparative study”, Journal of Education for Teaching, Vol. 35 No.1, pp. 3-18.

Smith, J. A. and Osborn, M. (2008), “Chapter 4, Interpretative phenomenological analysis”, in Smith, J.A. (Ed), Qualitative Psychology: A Practical Guide to Research Methods, Sage, London, pp. 53-80, 2nd ed.

Smith, J. A. and Osborn, M. (2015), “Chapter 4, Interpretative phenomenological analysis”, in Smith, J.A. (Ed), Qualitative Psychology: A Practical Guide to Research Methods, Sage, London, pp. 53-80, 3rd ed.

Struyven, K., Jacobs, K. and Dochy, F. (2013), "Why do they want to teach? The multiple reasons of different groups of students for undertaking teacher education”, European journal of psychology of education, Vol. 28 No. 3, pp. 1007-1022.

Sudzina, M. Giebelhaus, C. \& Coolican, M. (1997) "Mentor or Tormentor: The Role of the Cooperating Teacher in Student Teacher Success or Failure”, Action in Teacher Education, Vol. 18 No. 4, pp. 23-35.

Teaching Schools Council (2016) National Standards for school-based initial teacher training (ITT) mentors, Crown copyright. 
Trede, F., Macklin, R. and Bridges. D. (2012), “Professional identity development: a review of the higher education literature”, Studies in Higher Education, Vol. 37 No.3, pp.365-384.

Trust, T. and Horrocks, B. (2016), “'I never feel alone in my classroom’, teacher professional growth within a blended community of practice”, Professional Development in Education, DOI: 10.1080/19415257.2016.1233507

Vangrieken, K., Meredith, C., Packer, T., Kyndt, E. (2017), “Teacher communities as a context for professional development: A systematic review”, Teaching and Teacher Education, Vol. 61, pp. 47 - 59.

Wenger, E. (1998), Communities of practice: Learning, meaning, and identity. Cambridge University Press, Cambridge.

Wilkinson, S. (2015), “Chapter 9, Focus Groups”, in Smith, J.A. (Ed), Qualitative Psychology: A Practical Guide to Research Methods, Sage, London, pp.199 -221, 3rd ed.

Woodgate-Jones, A. (2012), “The student teacher and the school community of practice: an exploration of the contribution of the legitimate peripheral participant”, Educational Review, Vol. 64 No. 2, pp. 145-160.

Wright, V., Loughlin, T., Hall, V. (2017), “Lesson observation and feedback in relation to the developing identity of student teachers”, TEAN Journal, Vol. 9 No 2, pp. 100-112. 
